Sten G. E. Lindahl, MD PhD,

Kenneth P. Offord MS, Gunnar P. Johannesson MD, Donna M. Meyer, David J. Hatch MB BS FFarCS

\title{
Carbon dioxide elimination in anaesthetized children
}

Carbon dioxide elimination ( $\mathrm{VCO}_{2}$ ) was measured in 180 anaesthetized, spontaneously breathing infants and children with body weights ranging from 2.8 to $26.5 \mathrm{~kg}$. They all underwent minor paediatric surgical procedures. The influence on $\mathrm{VCO}_{2}$ of age, operation, premedication, caudal anaesthesia and different volatile anaesthetic agents was investigated. The volume of exhaled gas, during three- to five-minute collection periods, was measured and the fraction of exhaled $\mathrm{CO}_{2}$ was determined by a $\mathrm{CO}_{2}$ meter. Under basal anaestheric conditions, the average output before operation followed the equation: $\dot{V} \mathrm{CO}_{2}\left(\mathrm{ml} \cdot \mathrm{min}^{-1}\right)=-1.25 \mathrm{X}+13.0 \mathrm{X}^{2}$, in which $\mathrm{X}=$ $\mathrm{ln}_{\mathrm{e}}$ (body weight, $\mathrm{kg}$ ). Expressed on a weight basis, the youngest infants (weighing less than $5 \mathrm{~kg}$ ) had the lowest $\mathrm{vCO}_{2}$ Higher values were measured up to a body weight of $10 \mathrm{~kg}$ above which a negative correlation occurred between $\dot{V} \mathrm{CO}_{2}$ ( $\mathrm{mi} \cdot \mathrm{min}^{-1}-\mathrm{kg}^{-1}$ ) and body weight. The use of premedication resulted in a more variable $\mathrm{VCO}_{2}$ during operations than when opioid premedication was not used. The combination of a general anaesthetic and caudal anaesthesia stabilized $\mathrm{VCO}_{2}$ Also, children anaesthetized with halorhane had a higher $\mathrm{V} \mathrm{CO}_{2}$ than those who were anaesthetized with enflurane or isoflurane $(P<0.05)$. The variable $\dot{V} \mathrm{CO}_{2}$ emphasizes the need for increased monitoring of $\dot{\mathrm{V}} \mathrm{CO}_{2}$ during routine anaesthesia and operation in infants and children.

\section{Key words}

ANAESTHESIA: paediatric; ANAESTHETIC TECHNIQUES: inhalational, caudal; ANAESTHETICS, vOLATILE: enflurane, halothane, isoflurane; MEASUREMENT TECHNIQUES: capnography; METABOLISM: carbon dioxide production

From the Department of Anesthesiology and Section of Biostatistics, Mayo Clinic and Mayo Foundation, Rochester,

Minnesota and Department of Anaesthesia, The Hospital for Sick Children, Great Ormond Street, London, England.

Address correspondence to: Dr. Lindahl, Department of Anaesthesiology, University Hospital, S-221 85 Lund Sweden.

This study was supported by grants from The Wenner-

Gren Foundations and The Swedish Medical Research Council (Project No. B86-19X-007189-02A), Stockholm, Sweden, and Mayo Foundation, Rochester, Minnisota 55905, U.S.A
Carbon dioxide elimination is a valuable measure in clinical anaesthesia because it is related to metabolic rate and alveolar ventilation. ${ }^{1-3}$ The body content of $\mathrm{CO}_{2}$ is, however, large and the storage capacity is great. ${ }^{4}$ Significant changes in alveolar ventilation give rise to initial alterations in carbon dioxide output until a new respiratory steady-state level has been achieved. Because the body storage capacity of $\mathrm{CO}_{2}$ is so large, the finding of a new steady-state level is time-consuming. However, after 20 to 30 minutes of unchanged metabolism and ventilation, carbon dioxide elimination is approximated to a steadystate level. ${ }^{5}$ Although a complete steady state is rarely achieved during clinical anaesthesia, carbon dioxide elimination is most useful as an indicator of gas exchange, ventilatory levels, and metabolic stress.

The purpose of this study was to assess the influence of age and anaesthetic techniques on carbon dioxide elimination in anaesthetized infants and children. Different patient groups were investigated to illustrate the effects of surgery, premedication, inhalational anaesthetics, and caudal analgesia.

\section{Patients and methods}

The subjects of the study were 186 anaesthetized infants and children. Their ages ranged from one day to six years and their weight from 2.8 to $26.5 \mathrm{~kg}$. Most of the patients were scheduled for minor paediatric surgical procedures and were of ASA physical status I or II. The investigations, performed at different institutions, were approved by institutional review boards, and parental consent to the study was given in each case. The children were fasted for at least four to five hours before induction of anaesthesia. Children younger than one year arrived in the operating room without any opioid or sedative premedication. Older children were premedicated either with a rectal combination of diazepam, morphine, and hyoscine or with an intramuscular meperidine compound for those weighing less than $15 \mathrm{~kg}$ or papaveretum combined with hyoscine for those weighing more.

\section{Patient groups and anaesthesia}

Group A consisted of 39 infants and children with body weights ranging from 2.9 to $25.3 \mathrm{~kg}$ who had no cardiorespiratory disease. They were scheduled for 
minor paediatric surgical procedures. This group, being near to a respiratory steady state, constituted the reference group. These children received no premedication and had inhalational induction of anaesthesia with $\mathrm{O}_{2}-\mathrm{N}_{2} \mathrm{O}\left(\mathrm{FIO}_{2}\right.$, 0.5 ) and halothane. The trachea was intubated with cuffed tracheal tubes (Mallinkrodt) without the use of muscle relaxants. They were all spontaneously breathing a mixture of $\mathrm{O}_{2}$-air $\left(\mathrm{FlO}_{2}, 0.5\right)$ and halothane at minimal alveolar concentrations (MAC) of 0.8 to 1.2 , measured by a mass spectrometer (Perkin-Elmer, MGA 1103). Measurements were performed before the start of operation, 30 minutes after the induction of anaesthesia.

The 48 patients in Group B had body weights ranging from 2.8 to $20.5 \mathrm{~kg}$ and were studied during operation. They had normal cardiorespiratory functions and underwent minor paediatric surgical procedures. They were not premedicated, and anaesthesia was induced with $\mathrm{O}_{2}-\mathrm{N}_{2} \mathrm{O}$ ( $\mathrm{FIO}_{2}, 0.5$ ) and halothane in 24 patients and with oxygen in cyclopropane $\left(\mathrm{FlO}_{2}, 0.5\right)$ in 24 . After the induction of anaesthesia, intubation of the trachea was facilitated by administration of succinylcholine, 1 to $1.5 \mathrm{mg} \cdot \mathrm{kg}^{-1} \mathrm{IV}$. Once spontaneous ventilation had resumed, anaesthesia was maintained with $\mathrm{O}_{2}-\mathrm{N}_{2} \mathrm{O}\left(\mathrm{FIO}_{2}, 0.5\right)$, and inspired halothane concentrations of one to two per cent set by a calibrated Mark 3 vaporizer.

Group $C$ included 46 patients without cardiorespiratory disease who were older than one year; their body weights ranged from 10 to $25.5 \mathrm{~kg}$ and they were studied during operation. They had all received premedication before operation. In those weighing less than $15 \mathrm{~kg}$, an intramuscular injection of meperidine compound $\left(0.07 \mathrm{ml} \cdot \mathrm{kg}^{-1}\right)$ was injected IM 45 to 60 minutes before induction of anaesthesia. (Meperidine compound, $1 \mathrm{ml}$ contains: meperidine, $25 \mathrm{mg}$; promethazine, $6.25 \mathrm{mg}$; and chlorpromazine, $6.25 \mathrm{mg}$.) Children weighing more than $15 \mathrm{~kg}$ received papaveretum $\left(0.4 \mathrm{mg} \cdot \mathrm{kg}^{-1}\right)$ and hyoscine $\left(0.008 \mathrm{mg} \cdot \mathrm{kg}^{-1}\right)$ IM 45 to 60 minutes before induction of anaesthesia. These children also received atropine 0.2 to $0.4 \mathrm{mg} \mathrm{IM}$ at the time the other premedication was given. The trachea was intubated after succinylcholine administration ( 1.0 to $1.5 \mathrm{mg} \cdot \mathrm{kg}^{-1}$ ). When spontaneous breathing had resumed, anaesthesia was maintained with $\mathrm{O}_{2^{-}}$$\mathrm{N}_{2} \mathrm{O}\left(\mathrm{FIO}_{2}, 0.5\right)$ and inspired halothane concentrations of one to two per cent. No caudal anaesthesia was used.

Caudal anaesthesia using 0.25 per cent bupivacaine $\left(0.5 \mathrm{ml} \cdot \mathrm{kg}^{-1}\right)$ was established after induction of general anaesthesia in the 30 children in group D. These children underwent genital operations and had body weights ranging from 10.3 to $25.2 \mathrm{~kg}$. Their tracheas were intubated after administration of succinylcholine (1.0 to $1.5 \mathrm{mg} \cdot \mathrm{kg}^{-1}$ ), and they were allowed to breathe $\mathrm{O}_{2}-\mathrm{N}_{2} \mathrm{O}$ $\left(\mathrm{FIO}_{2}, 0.5\right)$ and inspired halothane concentrations of 0.75 to 1.25 per cent. The children were premedicated with intramuscular injections of either meperidine compound or papaveretum in combination with hyoscine, as described above.

The effects of volatile anaesthetic agents on carbon dioxide elimination were studied in the 23 patients in group E. All 23 children had received a rectal premedication of diazepam $\left(0.5 \mathrm{mg} \cdot \mathrm{kg}^{-1}\right)$, morphine $(0.15$ $\left.\mathrm{mg} \cdot \mathrm{kg}^{-1}\right)$, and hyoscine $\left(0.01 \mathrm{mg} \cdot \mathrm{kg}^{-1}\right)$, which was administered 45 to 60 minutes before the induction of anaesthesia. All the children were free from cardiorespiratory disease and were subjected to lower abdominal or genital surgical procedures. After the induction of anaesthesia, succinylcholine ( 1.0 to $1.5 \mathrm{mg} \cdot \mathrm{kg}^{-1}$ ) was given to facilitate intubation of the trachea, and the children were then allowed to breathe spontaneously. All had received caudal anaesthesia with 0.25 per cent bupivacaine $(0.5$ $\mathrm{ml} \cdot \mathrm{kg}^{-1}$ ) administered after the induction of general anaesthesia. Eight children with body weights ranging from 13.7 to $24.0 \mathrm{~kg}$ received enflurane in $\mathrm{O}_{2}-\mathrm{N}_{2} \mathrm{O}\left(\mathrm{FiO}_{2}\right.$, 0.5 ) at a MAC value of 0.92 , eight with body weights ranging from 10.7 to $26.5 \mathrm{~kg}$ received isoflurane in $\mathrm{O}_{2}-\mathrm{N}_{2} \mathrm{O}\left(\mathrm{FIO}_{2}, 0.5\right)$ at a MAC value of 0.92 , and seven with body weights between 12 and $24.5 \mathrm{~kg}$ received halothane in $\mathrm{O}_{2}-\mathrm{N}_{2} \mathrm{O}\left(\mathrm{FlO}_{2}, 0.5\right)$ at a $\mathrm{MAC}$ value of 0.97 . Calculations of $\mathrm{MAC}$ values were corrected for age, ${ }^{6-9}$ and ten per cent of nitrous oxide was regarded to be equivalent to $0.1 \mathrm{MAC}^{10}$

\section{Measurements}

No measurements were done until 20 to 30 minutes after the induction of anaesthesia. In most patients, a Mapleson D system was used, and fresh gas flows were set high enough to eliminate rebreathing, as indicated on the in-line $\mathrm{CO}_{2}$ meter (Hewlett-Packard, 14360A). In some patients, a non-rebreathing valve with low inspiratory and expiratory resistances was used (AMBU PediAnaesthesia System), and an in-line $\mathrm{CO}_{2}$ meter was also used for detection of possible rebreathing. The $\mathrm{CO}_{2}$ meter was calibrated by two known concentrations of $\mathrm{CO}_{2}$ and corrections for $\mathrm{N}_{2} \mathrm{O}$, due to the collison broadening effect of $\mathrm{N}_{2} \mathrm{O}$ on the infrared spectrum, were performed when $\mathrm{N}_{2} \mathrm{O}$ was in use. Expired gas was collected in a Douglas bag during three- to five-minute periods. The mean expired carbon dioxide fraction $\left(\mathrm{FECO}_{2}\right)$ was measured with the $\mathrm{CO}_{2}$ meter. Exhaled gas volumes were measured with either a standard gas meter, (AB Nordgas, Stockholm, Sweden), or with a supersyringe.

Carbon dioxide elimination $\left(\mathrm{VCO}_{2}\right)$ was calculated according to the following formula:

$\dot{\mathrm{V}} \mathrm{CO}_{2}\left(\mathrm{~m} \cdot \cdot \mathrm{min}^{-1}\right)=$ gas collection $\dot{\mathrm{V}} \times \mathrm{FECO}_{2}$

where inspired $\mathrm{CO}_{2}$ concentration was zero in all measurements and in which gas collection $\dot{V}_{E}$ indicates the 
expired gas collection volume during four- to five-minute collection periods. All $\mathrm{CO}_{2}$ yalues are presented at ambient temperature and pressure, saturated. The accuracy and precision of the $\mathrm{CO}_{2}$ meter were investigated by repeated measurements of the same certified gas concentrations. The largest deviation was 0.022 per cent or less than $1 \mathrm{mmHg}$.

\section{Statistics}

Mean values and standard deviations were calculated. Numerous linear and polynomial regressions were used to model the relationship between $\mathrm{VCO}_{2}$ and body weight. Transformations to logarithmic scales and fitting models without intercept terms were also explored. To predict normal values, not only the predicted mean value but also the variation about the predicted value was considered by modeling the residual as a second step after fitting the equation used to obtain the predicted mean $\dot{\mathrm{VCO}}_{2}$. Analysis of covariance was used to compare $\dot{\mathrm{VCO}}_{2}$ levels for patients receiving halothane, isoflurane, and enflurane, adjusted for body weight.

\section{Results}

Body temperatures varied between $36-38^{\circ} \mathrm{C}$. Blood pressures changed with age. During measurements, no subnormal blood pressures were recorded. In group B, in which anaesthesia was induced with cyclopropane in 24 children and with halothane in $\mathrm{O}_{2}-\mathrm{N}_{2} \mathrm{O}$ in another 24 children, the $\mathrm{VCO}_{2}$ value did not differ with the induction technique used. In the comparison of various volatile anaesthetic agents (group E), body weights and MAC values were similar in all three groups.

\section{Carbon dioxide output - before operation, no caudal} anaesthesia and no premedication (group A)

The $\dot{\mathrm{V}} \mathrm{CO}_{2}$ was related to body weight according to the diagram shown in Figure 1 for the 39 children in group $A$. The predicted mean value of $\mathrm{VCO}_{2}$ followed the relationship: $\dot{V} \mathrm{CO}_{2}\left(\mathrm{ml} \cdot \mathrm{min}^{-1}\right)=-1.25 \mathrm{X}+13.0 \mathrm{X}^{2}$ in which $X=\ln _{\mathrm{e}}$ (body weight, $\mathrm{kg}$ ). This model was obtained by a least-squares fit of a second degree polynomial with a zero intercept. Note that this model forces the predicted $\dot{\mathrm{V}} \mathrm{CO}_{2}$ to be zero when body weight is $1 \mathrm{~kg}$ because $\ln _{\mathrm{c}}$ (1) $=0$. The range from the lower 2.5 per cent to the upper 97.5 per cent percentile was calculated according to the following equation: predicted mean $\mathrm{VCO}_{2} \pm$ $2.0 \times \sqrt{-24.0+12.3 \times \text { body weight. }}$ Corresponding to these equations, a $10-\mathrm{kg}$ child would have a predicted $\mathrm{VCO}_{2}$ of $66 \pm 20 \mathrm{ml} \cdot \mathrm{min}^{-1}$. The sigmoid shape in the lower range of the mean predicted $\dot{\mathrm{VCO}}_{2}$ curve demonstrates a decreased elimination of $\mathrm{CO}_{2}$ per kilogram in infants

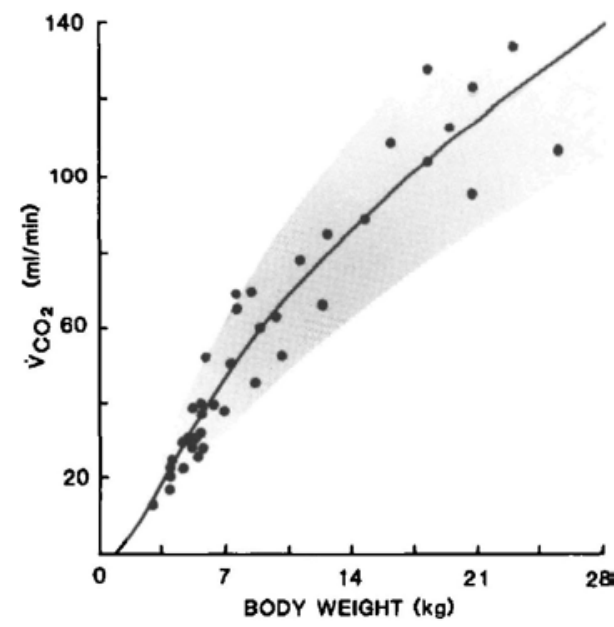

FIGURE 1 Carbon dioxide elimination ( $\left(\mathrm{CO}_{2}\right)$ in relation to body weight in 39 infants and children who were studied before operation and who did not receive caudal anaesthesia or premedication (group A). The continuous line represents the predicted mean valuc, and the shaded area is the 95 per cent confidence interval for individual ralues.

compared with younger children. The mean value ( \pm SD) for all 39 children was $6.1 \pm 1.2 \mathrm{ml} \cdot \mathrm{min}^{-1} \cdot \mathrm{kg}^{-1}$. The mean value ( $\pm \mathrm{SD}$ ) was $5.8 \pm 1.2 \mathrm{ml} \cdot \mathrm{min}^{-1} \cdot \mathrm{kg}^{-1}$ for the children weighing between 2.9 and $5 \mathrm{~kg}$, and it was $6.3 \pm$ $1.2 \mathrm{ml} \cdot \mathrm{min}^{-1} \cdot \mathrm{kg}^{-1}$ for those weighing more than $5 \mathrm{~kg}$.

\section{Carbon dioxide output during operation}

\section{WITHOUT PREMEDICATION (gIOUP B)}

The children who had not received any premedication were often younger than one year. The $\mathrm{VCO}_{2}$ during operation was within the normal range for the output measured before operation (Figure 2a). The mean value $( \pm \mathrm{SD})$ was $6.2 \pm 1.7 \mathrm{ml} \cdot \mathrm{min}^{-1} \cdot \mathrm{kg}^{-1}$.

\section{WITH PREMEDICATION (group C)}

Premedicated children had a greater range for $\dot{\mathrm{V}} \mathrm{CO}_{2}$ during operation than those who were not premedicated and studied before operation (Figure $2 b$ ) and than those who had not received premedication but underwent operation (Figure $2 a$ ). The mean value $( \pm \mathrm{SD}$ ) for children in group $\mathrm{C}$ was $5.7 \pm 1.5 \mathrm{ml} \cdot \mathrm{min}^{-1} \cdot \mathrm{kg}^{-1}$. 

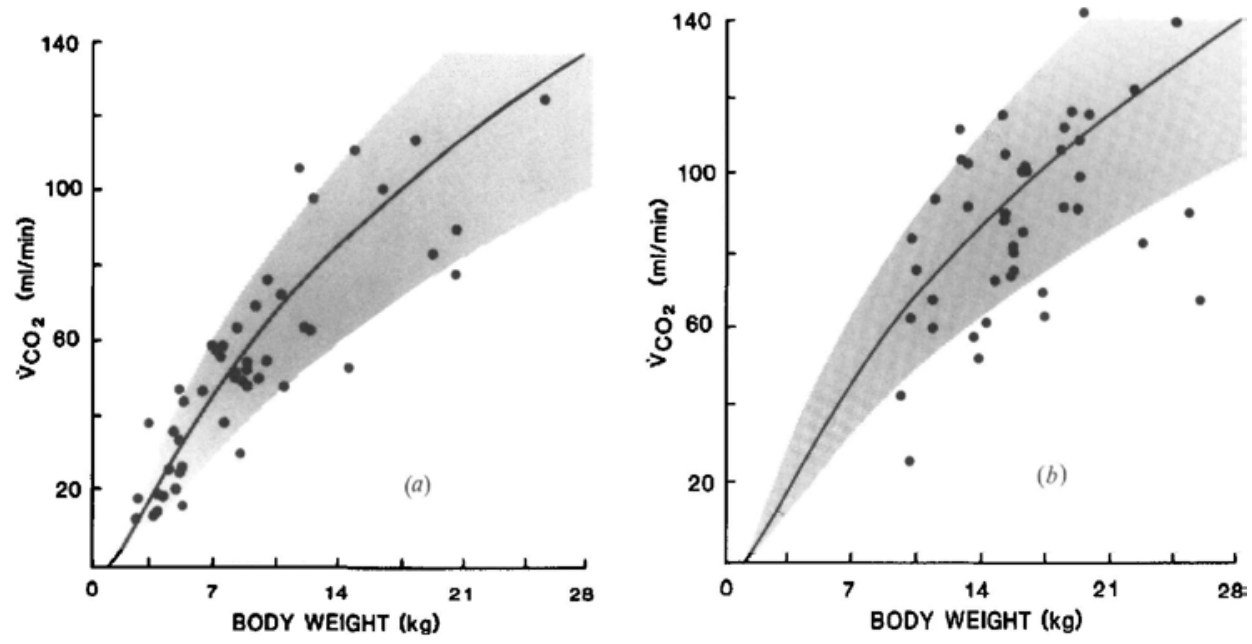

FIGURES $2 a$ and $2 b$ (a) Carbon dioxide elimination ( $\left(\mathrm{VCO}_{2}\right.$ ) in relation to body weight during operation in unpremedicated children (group $\mathrm{B}$ ). (b) Relationship between $\mathrm{VCO}_{2}$ and body weight in premedicated children who underwent operation (group C). Neither group $\mathbf{B}$ nor group $\mathrm{C}$ received any caudal anaesthesia. Note the greater variability in children who had received premedication than in those who did not. Shaded area represents the confidence interval for the $\mathrm{VCO}_{2}$ in unpremedicated patients before operation, and the continuous line is the predicted mean in group $A$, as shown in Figure 1.

\section{Carbon dioxide output and caudal anaesthesia (group D)}

The $\dot{\mathrm{VCO}}_{2}$ was less variable during operation when caudal anaesthesia was combined with inhalation anaesthesia in children who had had opioid premedication (Figure 3) than in those who did not receive caudal anaesthesia (Figure $2 b$ ). There was a tendency toward a lower $\mathrm{CO}_{2}$ output than in children who did not have caudal anaesthesia, although the differences in mean values were not statistically significant (Figure 3).

\section{Carbon dioxide output and volatile anaesthetic agents (group E)}

The 23 children in this group had all received cauda anaesthesia and opioid premedication. Most of those anaesthetized with enflurane and isoflurane had a $\dot{\mathrm{VCO}}_{2}$ that was lower than the mean $\dot{\mathrm{CO}}_{2}$, adjusted for body weight among the three groups using an analysis of covariance. Those patients anaesthetized with halothane had outputs similar to the predicted mean $\mathrm{VCO}_{2}$ (Figure 4). The differences in $\mathrm{VCO}_{2}$ between those receiving halothane and enflurane on the one hand and between those receiving halothane and isoflurane on the other hand were statistically significant $(P<0.05$ and $P<0.05$, respectively; Figure 4).

\section{Discussion}

In previous studies, $\dot{\mathrm{V}} \mathrm{CO}_{2}$ during anaesthesia and operation has been shown to be higher in younger than in older children when expressed on a weight basis. ${ }^{11,12}$ This observation is also true for anaesthetized children older than one year or who weigh more than $10 \mathrm{~kg}$. For those weighing less than $10 \mathrm{~kg}, \mathrm{VCO}_{2}$ becomes unpredictable, and it is often lower than in children weighing more than $10 \mathrm{~kg} .{ }^{11-13}$ When the formula for predicted $\mathrm{VCO}_{2}$ presented in this study was used for the calculation of average $\mathrm{VCO}_{2}$ in healthy, non-premedicated, spontaneously breathing infants and children, the average child of $3 \mathrm{~kg}$ eliminated $4.8 \mathrm{ml} \cdot \mathrm{min}^{-1} \cdot \mathrm{kg}^{-1}$ whereas a child weighing $7 \mathrm{~kg}$ eliminated $6.7 \mathrm{ml} \cdot \mathrm{min}^{-1} \cdot \mathrm{kg}^{-1}$, an increase of 40 per cent. These findings are in agreement with earlier results in infants. ${ }^{11-13}$ In older children, however, $\dot{\mathrm{V} C O}$ decreased with increasing age when $\mathrm{V}_{\mathrm{CO}}$ was expressed on a per kilogram of body weight basis. This is exemplified by the child weighing $12 \mathrm{~kg}$ who had a $\mathrm{VCO}_{2}$ of $6.4 \mathrm{ml} \cdot \mathrm{min}^{-1} \cdot \mathrm{kg}^{-1}$ and by the child weighing $20 \mathrm{~kg}$ 




FGURE 3 Carbon dioxide elimination $\left(\mathrm{VCO}_{2}\right)$ in relation to body weight during operation in children who had received caudal anaesthesia and premedication (group D). In most patients, the $\mathrm{VCO}_{2}$ was within the nomal range (group $A$ ), which is indicated by the shaded arca, und the predicted mean $\mathrm{VCO}_{2}$ ousput for group $\mathrm{A}$ is indicated by the continuous line.

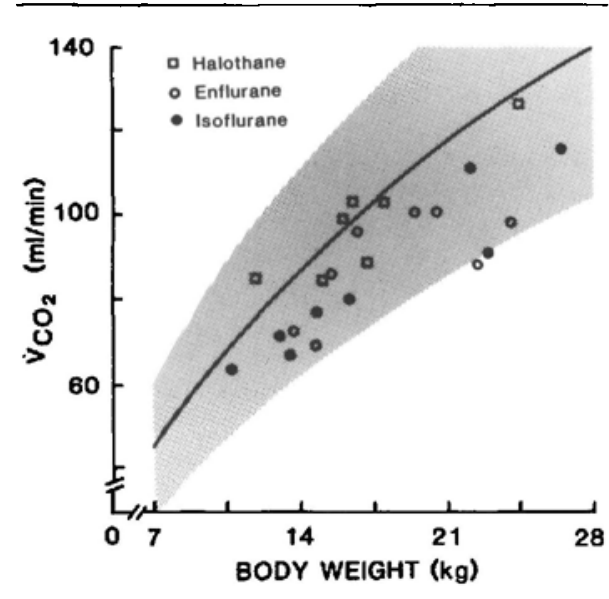

FGURE 4 Carbon dioxide elimination $\left(\mathrm{VCO}_{2}\right)$ in relation to body weight for children who were spontaneously breathing halothase (open squares), enflurane (open circles), or isoflurane (closed circles) (group E). Note that patients anaesthetized with halothane had outputs that followed and were near to the predicted values, whereas children who received enflurane or isoflurane had outputs that were in the lower range or just below the normal range (indicated by the shaded area). who eliminated $5.7 \mathrm{ml} \cdot \mathrm{min}^{-1} \cdot \mathrm{kg}^{-1}$. Thus, the $\dot{\mathrm{V}} \mathrm{CO}_{2}$ is expected to be lower in anaesthetized neonates and young infants than in young children. Furthennore, because $\dot{\mathrm{V}} \mathrm{CO}_{2}$ is more variable in infants than in children, 11,12 the indications increase for $\mathrm{CO}_{2}$ monitoring during anaesthesia and operation in patients of this age.

The $\mathrm{VCO}_{2}$ was expected to be enhanced during operation compared with a steady state of anaesthesia just before surgical stimulation, particularly if the children were not premedicated. This was, however, not the case and could most probably be explained by the fact that the surgical procedures were minor lower abdominal operations with only negligible sympathetic reactions to the surgical trauma. Surprisingly, $\mathrm{vCO}_{2}$ showed a greater range in children who had received opioid premedication than in those who were not premedicated, although mean values did not differ. Premedication should result in a lower metabolic stress ${ }^{14.15}$ and hence in a more stable gas exchange during operation. However, plasma concentrations of drugs used for premedication, sometimes administered up to 90 minutes before measurements during ansesthesia, may vary. Thus, the premedication may have had a good effect in some patients or the effect of the premedication may have almost wom off in others; as a result, the variability of $\mathrm{VCO}_{2}$ in premedicated infants and children was increased when compared with the finding in the patients who were not premedicated.

Caudal anaesthesia, in addition to a general anaesthetic, is frequently used to diminish surgical stress during genital or lower abdominal operations in paediatric patients. Benefits from the combination of a regional anaesthetic technique and general anaesthesia, as far as surgical stress response is concerned, have been documented in previous investigations. ${ }^{16.17}$ When the children who received caudal anaesthesia in the present series were compared with those who did not, a somewhat lower and less variable $\mathrm{VCO}_{2}$ was found. This finding demonstrates a more stable gas exchange, which suggests the liberal use of caudal anaesthesia in combination with general anaesthesia for minor lower abdominal surgical procedures in paediatric patients.

Despite patients having similar MAC values and comparable ages and body weights, $\mathrm{vCO}_{2}$ was higher during halothane anaesthesia than during enflurane or isoflurane anaesthesia. This increased output may be caused by the different effects of these volatile anaesthetic agents on catecholamine surge during anaesthesia, in that halothane anaesthesia is related to higher plasma catecholamine concentrations than enflurane and isoflurane ${ }^{18}$ and since increased plasma catecholamines may raise the metabolic rate and hence $\mathrm{CO}_{2}$ output. This explanation is in conformity with the finding of Joyce et al., ${ }^{19}$ who showed an increased surge of norepinephrine after induc- 
tion of anaesthesia with halothane. The observation of a higher $\dot{\mathrm{V}} \mathrm{CO}_{2}$ with halothane anaesthesia has to be further investigated in controlled metabolic studies using the three volatile anaesthetic agents, halothane, enflurane, and isoflurane. However, the observation again demonstrates that there are unexpected variations of $\mathrm{VCO}_{2}$ during anaesthesia and operation and emphasizes the need for its increased routine monitoring during anaesthesia in paediatric patients.

We conclude that the average $\dot{\mathrm{V}} \mathrm{CO}_{2}$ is lower in young infants than in older infants and children when expressed on a weight basis. Opioid premedication does not seem to have any stabilizing effects on $\mathrm{VCO}_{2}$ during operation in children, whereas caudal anaesthesia in combination with general anaesthesia does have a stabilizing effect. Halothane anaesthesia was associated with a higher ${ }_{\mathrm{V}} \mathrm{CO}_{2}$ than enflurane or isoflurane anaesthesia.

\section{Acknowledgment}

The authors are grateful to Mr. Jon Strauss for excellent technical assistance.

\section{References}

1 de Weir VJB. New methods for calculating metabolic rate with special reference to protein metabolism. J Physiol 1949; 109: 1-9.

2 Lowe HJ, Ernst EA (Eds.). The quantitative practice of anesthesia: use of closed circuit. Baltimore: Williams \& Wilkins, 1981: 149.

3 Nelson NM, Prod'hom LS, Cherry RB, Lipsitz PJ, Smith $C A$. Pulmonary function in the newborn infant. I. Methods: ventilation and gaseous metabolism. Pediatrics 1962; 30: 963-74.

4 Cherniack NS, Longobardo GS. Oxygen and carbon dioxide gas stores of the body. Physiol Rev 1970; 50: 196-243.

5 Farhi $L E$, Rahn $H$. Gas stores of the body and the unsteady state. J Appl Physiol 1955; 7: 472-84.

6 Gregory GA, Eger EI II, Munson ES. The relationship between age and halothane requirement in man. Anesthesiology 1969; 30: 488-91.

7 Lerman I, Robinson S, Willis MM, Gregory GA. Anesthetic requirements for halothane in young children 0-1 month and 1-6 months of age. Anesthesiology 1983; 59 : $421-4$.

8 Cameron $C B$, Robinson S, Gregory GA. The mirimum anesthetic concentration of isoflurane in children. Anesth Analg 1984; 63: 418-20.

9 Gion $H$, Saidman $L J$. The minimum alveolar concentration of enflurane in man. Ancsthesiology 1971; 35: $361-4$.
10 Quasha AL, Eger EI II. Tinker JH. Determination and applications of MAC. Anesthesiology 1980; 53: 31534.

11 Nightingale DA, Lambert TF. Carbon dioxide output in anaesthetised children. Anaesthesia 1978; 33: 594-600.

12 Lindahl $S$, Olsson A-K, Thomson D. Carbon dioxide output in spontaneously breathing infants during anaesthesia and surgery. Br J Anaesth 1981; 53: 647-51.

13 Olsson A-K, Lindahl SGE. Pulmonary ventilation, $\mathrm{CO}_{2}$ response and inspiratory drive in spontaneously breathing young infants during halothane anacsthesia. Acta Anaesthesiol Scand 1986; 30; 431-7.

14 Sigurdsson $G$, Lindahl $S$, Norden $N$. Influence of premedication on plasma $\mathrm{ACTH}$ and cortisol concentrations in children during adenoidectomy. $\mathrm{Br} \mathrm{J}$ Anaesth 1982; 54 : 1075-80.

15 Sigurdsson GH, Lindahl S, Norden $N$. Influence of premedication on the sympathetic and endocrine responses and cardiac arrhythmias during halothane anaesthesia in children undergoing adenoidectomy. Br J Anaesth 1983; 55: 961-8.

16 Engquist $A$, Brandt MR, Fernandes $A$, Kehtet $H$. The blocking effect of epidural analgesia on the adrenocortical and hyperglycemic responses to surgery. Acta Anacsthesiol Scand 1977; 21: 330-5.

17 Engquist A, Fog-Moller F, Christiansen C, Thode J, Vester-Andersen T, Madsen SN. Influence of epidural analgesia and the catecholamine and cyclic AMP responses to surgery. Acta Anaesthesiol Scand 1980; 24: 17-21.

18 Johannesson GP, Lindahl SGE, Sigurdsson GH, Norden $N E$. Halothane, enflurane and isoflurane anaesthesia for adenoidectomy in children, using two different premedications. Acta Anaesthesiol Scand 1987; 31: 233-8.

19 Joyce JT, Roizen MF, Gerson JI, Grobecker H, Eger EIII, Forbes $A R$. Induction of anesthesia with halothane increases plasma norepinephrine concentrations. Anesthesiology 1982; 56: 286-90.

\section{Résumé}

L'éliminasion du $\mathrm{CO}_{2}\left(\mathrm{~V}_{\mathrm{CO}} \mathrm{O}_{2}\right)$ a été mesurée chez 186 nouveau-nés et enfants dont le poids variait de 2.8 d $26.5 \mathrm{~kg}$ respirant spontanément. Tous ont subi une opération chirurgicale mineure. L'influence sur la $\dot{\mathrm{V}} \mathrm{CO}_{2}$ de l'age, l'opération, la prémédication, l'anesthésie caudale et les différents agents anesthésiques volatils ont été investigués. Le volume du gaz expiré. pour des périodes de collection de trois a cinq minutes, était mesuré et la fraction du $\mathrm{CO}_{2}$ expiré étail dëterminée par un capnomètre. Sous des condizions anesthésiques normales, l'élimination moyenne duran l'opération correspondair a l'équation: $\dot{V} \mathrm{CO}_{z}\left(\mathrm{ml} \cdot \mathrm{min}^{-1}\right)=$ $-1.25 \mathrm{X}+13.0 \mathrm{X}^{2}$ ou $\mathrm{X}=\mathrm{ln} \mathrm{e}$ (poids corporel, $\mathrm{kg}$ ). Exprimés selon le poids, les nouveau-nés (pesant moins que $5 \mathrm{~kg}$ ) avaien les valeurs de $\mathrm{VCO}_{2}$ les plus basses. Les valeurs plus élevées 
étaient mesurées jusqu'd̀ un poids de $10 \mathrm{~kg}$ au-delà duquel une corrélation négative est survenue entre la $\dot{\mathrm{V} C \mathrm{O}_{2}}\left(\mathrm{ml} \cdot \mathrm{min}^{-1}\right.$. $\mathrm{kg}^{-1}$ ) et le poids corporel. La prémédication a amené des variations dans les valeurs de la $\mathrm{VCO}_{2}$ durant les opérations alors qu'on n'a retrouvé aucune variation en l'absence de prémédication. L'association de l'anesthésie générale et de l'amesthésie caudale a stabilisé la $\mathrm{VCO}_{2}$. Aussi les enfants anesthésiés avec l' halothane avaient des valeurs de $\mathrm{V}_{\mathrm{CO}}$ plus élevées que ceux anesthésiés avec l'enflurane ou l' isoflurane ( $P$ $<0.05$ ). La variation de la $\dot{\mathrm{VCO}}{ }_{2}$ suggère la nécessité de la surveiller durant une anesthésie de routine chez les nouveau-nés et les enfants. 